Vol 1 No 22020 Desember 2020

Jurnal AlphaEuclidEdu

Received: 21/10/2020; Revised: 30/11/2020; Accepted: 08/12/2020

\title{
MISKONSEPSI SISWA DALAM MENYELESAIKAN SOAL HIMPUNAN BERDASARKAN TAHAPAN MASON
}

\author{
${ }^{1}$ Melianti, Dwi Andi, ${ }^{2}$ Yusmin, Edy, ${ }^{3}$ Nursangaji, Asep \\ 1,2,3Pendidikan Matematika FKIP Universitas Tanjungpura Pontianak \\ Email: andydwi108@gmail.com
}

\begin{abstract}
There are facts obtained through interviews and observations of students' answers that the VII grade students of SMP LKIA Pontianak are suspected of having misconceptions. Based on theses facts, the purpose of this research is to reveal the form of misconception based on Mason stages and the causes of the misconception. The subjects involved in this research were fifteen students. This research is a case study research with a descriptive method. Data collection tools used modified CRI diagnostic tests and interviews. Based on data analysis, the misconceptions experienced by students in completing set operations consisted of notation misconceptions, generalization and specialization. Researchers found out of the three forms of misconception, the most common is notation misconception. In the problem solving stage according to Mason consists of three stages, namely entry, attack, and review, students who experience misconceptions in two stages, namely at the entry stage, students experience notation misconceptions and at the review stage, students experience misconceptions of notation, generalization, and specialization. Researchers found the causes of misconceptions consisted of three factors, namely students' associative thinking, incomplete / wrong reasoning, and wrong intuition. Researchers found out of the three forms of misconception, the most common is wrong intuition.

Keyword: Causes of Misconceptions, Mason Stages, Misconceptions
\end{abstract}

\section{Pendahuluan}

Pembelajaran bidang studi matematika memiliki beberapa tujuan yang termuat dalam Permendiknas No. 22 tahun 2006, yaitu memahami, menjelaskan keterkaitan, dan mengaplikasikan konsep. Siswa dengan jenjang SMP/MTs/SMPLB dan sederajat, pengetahuan konseptual menjadi salah satu aspek yang terdapat dalam kompetensi yang termuat didalam Permendikbud No. 20 tahun 2016. Berdasarkan hal tersebut, pengetahuan konseptual sangat berarti, sehingga miskonsepsi (kesalahan dalam pengetahuan konseptual) harus diperkecil untuk terjadi dikalangan siswa. Edogawatte mengungkapkan bahwa ada 3 jenis kesalahan dalam menyelesaikan soal, yaitu salah algoritma (faulty algorithms), salah konsep (misconception), dan error (kesalahan akibat kurang teliti) (Edogawatte, 2011). Secara etimologis, miskonsepsi berasal dari bahasa inggris yaitu misconception, secara bahasa dapat diartikan sebagai kesalah pahaman. Cambridge Advance Learner's Dictionary mendefinisikan misconception is an idea that is wrong because it has been based on a failure to understanding a situation yang berarti miskonsepsi adalah sebuah ide yang salah karena didasarkan pada kegagalan untuk memahami suatu situasi.

Tracht menyatakan bahwa bidang studi matematika merupakan pembelajaran yang banyak menerapkan konsep-konsep (Tracht, 2011). Ozkan menyatakan konsep satu dengan konsep yang lainnya saling berkesinambungan, apabila satu diantara konsep yang saling berkesinambungan itu tidak dimengerti, sehingga akan menimbulkan dampak terhadap pemahaman konsep yang lainnya. Siswa dapat membuat pengertian sendiri terhadap suatu konsep hal ini disebabkan pemahaman yang rendah terhadap suatu konsep (Ozkan, 2011). Sesuai yang dikatakan Suparno dapat diambil kesimpulan bahwa miskonsepsi merupakan kata yang digunakan untuk mendeskripsikan suatu konsep yang tidak sesuai dengan pemahaman ilmiah atau pemahaman yang 
diterima oleh bidang yang terkait (Suparno, 2013). Kunh menyatakan bahwa miskonsepsi dapat menghambat pembelajaran baru (Kunh, 2009). Satu diantara topik ulasan yang dipelajari dijenjang SMP yaitu materi himpunan. Terkait materi himpunan ada beberapa tujuan pembelajaran yang ingin dicapai antaranya siswa diharapkan mampu mendefinisikan himpunan, mengetahui jeni-jenis himpunan, dan menyelesaikan opersai himpunan. Berdasarkan Standar kompetensi yang telah dibuat oleh Permendikbud yang diharapkan pada topik ini adalah memanfaatkan konsep himpunan dan diagram Venn untuk pemecahan masalah.

Fakta yang terjadi di lapangan berdasarkan hasil wawancara tak terstruktur dari guru matematika di SMP LKIA Pontianak kelas VII, didapatkan keterangan bahwa tujuan pembelajaran belum memuaskan berdasarkan tuturan guru tersebut, terutama pada sub menyelesaikan soal opersai himpunan. Akibatnya hasil belajar siswa kurang baik pada materi himpunan. Hal ini didukung oleh data rata-rata nilai 25 siswa kelas VII SMP LKIA Pontianak tahun ajaran 2019/2020 pada operasi himpunan sebesar 62,76 dikatagorikan tidak tuntas dengan KKM 75. Dari 25 jumlah siswa kelas VII 9 orang siswa tuntas atau 36\% siswa dan 16 orang siswa lainnya tidak tuntas atau 64\% siswa. Berdasarkan hasil prariset, didapatkan siswa yang mengalami salah pemahaman dalam mengubah notasi numerik untuk mendapatkan anggota himpunan $A$ yaitu $A=\{x \mid x \leq 10$, $\mathrm{x} \in$ bilangan asli $\}$, pekerjaan siswa menjawab " $\mathrm{A}=\{1,2,3,4,5,6,7,8,9\}$ " sedangkan yang sebenarnya adalah " $\mathrm{A}=\{1,2,3,4,5,6,7,8,9,10\}$ ”, hal tersebut mengidentifikasikan bahwa siswa tersebut mengalami miskonsepsi notasi dan siswa tersebut salah melakukan pengoperasian gabungan dari himpunan yaitu "AUB $=\{1,2$, $3,4,5,6,7,8\}$ " sedangkan yang sebenarnya adalah "AUB $=\{1,2,3,4,5,6,7,8,9\}$ " hal tersebut mengidentifikasikan bahwa siswa tersebut mengalami miskonsepsi penggeneralisasian.

Hal tersebut terjadi karena beberapa faktor satu diantaranya diduga telah terjadi kesalahan konsep siswa dalam operasi himpunan. Guru tersebut bertutur ada beberapa siswa yang tidak paham maksud soal dan salah membaca simbol yang dipakai dalam operasi himpunan sehingga dalam mencari hasil dari operasi tersebut mereka mendapat jawaban yang keliru. Adanya kesalahan konsep ini perlu dianalisis untuk mengetahui bentuk miskonsepsi yang dialami dan faktor penyebabnya. Hasan mengemukakan suatu metode yang digunakan untuk mengenali miskonsepsi sekaligus memilah siswa yang paham konsep dan yang tidak paham konsep (dalam Tayubi, 2005). Metode yang diajukan tersebut bernama CRI (Certainty of Response Index). Tes pemahaman konsep yang dilengkapi oleh CRI termodifikasi oleh Aliefman Hakim ini yang digunakan oleh peneliti pada penelitian ini. CRI merupakan suatu skala ukuran tingkat keyakinan yang telah ditetapkan untuk pihak-pihak yang dijadikan sebagai sempel dalam sebuah penelitian ketika menjawab setiap pertanyaan yang terdapat di dalam soal. CRI termodifikasi didasarkan pada suatu skala dan diberikan bersamaan dengan setiap jawaban dan alasan jawaban tersebut.

Depdiknas (2006: 148) menyatakan bahwa bidang studi pembelajaran matematika untuk tahapan menyelesaikan masalah adalah satu di antara tujuan yang hendak dicapai 
dalam pembelajarannya. Dalam menyelesaikan suatu masalah, siswa harus melewati beberapa tahap yaitu mengidentifikasi, menyelesaikan, dan membuat hubungan di antara beberapa hukum atau teori (Siregar, 2010). Berdasarkan pernyataan tersebut, kemampuan dalam menyelesaikan masalah sangat diperlukan dalam menghadapi suatu masalah. Tahapan penyelesaian masalah mampu dirambah dengan berbagai pengamatan yang didasarkan atas tahapan Polya, yaitu memahami, merencanakan, melaksanakan, dan melihat kembali. Ada juga, tahapan penyelesaian masalah mampu dirambah dengan tahapan Mason , dkk (2010). Menurut Mason terdapat tiga tahapan yang dilalui oleh seseorang untuk menyelesaikan masalah, yaitu entry, attack, dan review (Mason, 2010).

Tahapan penyelesaian masalah yang dikemukaan Polya (1973) sejalan dengan tahapan yang dikemukakan oleh Mason, dkk (2010) (Helda, 2016). Hal ini didukung oleh pernyataan Lin (2007) yang menyatakan bahwa tahapan penyelesaian masalah Mason didasarkan oleh pemikiran Polya. Dengan pembagian tahapan Mason membantu peneliti untuk menemukan jenis miskonsepsi yang tejadi berdasarkan tahapan dalam menyelesaikan masalah. Hal ini didukung oleh penelitian yang dilakukan Karolin (2016) yang berjudul tentang kesalah pahaman konsep dalam menyelesaikan soal aljabar siswa kelas VIII berdasarkan proses berpikir Mason yang didapatkan kesimpulan bahwa pada tahap entry dan review yang dicetuskan oleh Mason pada penelitian Karolin siswa tidak mengalami kesalah pahaman konsep, namun pada tahap attack siswa mengalami kesalah pahaman konsep dalam materi aljabar.

Berdasarkan paparan di atas peneliti sangat terdorong untuk mengetahui apa saja bentuk miskonsepsi yang dialami siswa saat menyelesaikan soal operasi himpunan berdasarkan tahapan Mason di kelas VII sekolah menengah pertama dan penyebab miskonsepsi yang dialami siswa saat menyelesaikan soal operasi himpunan. Tujuan yang ingin dicapai peneliti adalah untuk mengungkap bentuk miskonsepsi yang dialami siswa saat menyelesaikan soal operasi himpunan berdasarkan tahapan Mason di kelas VII sekolah menengah pertama dan untuk mengungkap penyebab miskonsepsi yang dialami siswa tersebut.

\section{Metode Penelitian}

Metode deskriptif adalah metode yang dipakai dalam penelitian ini, dengan jenis penelitian case study. Adapun yang menjadi pertimbangan memilih penelitian studi kasus antara lain karena penelitian ini memuaskan perhatian pada suatu kasus yaitu siswa yang mengalami miskonsepsi dalam suatu kelas. Dalam penelitian ini akan mengungkap miskonsepsi siswa dalam menyelesaiakan soal operasi himpunan berdasarkan tahapan Mason dan penyebab terjadinya miskosepsi. Miskonsepsi dapat ditemukan dari jawaban pada tes diagnostic CRI termodifikasi.

Tes pemahaman konsep (teknik tes) dan wawancara (teknik non tes) merupakan teknik pengumpulan data yang dipergunakan oleh peneliti dalam penelitian ini. Soal tes yang diberikan yaitu tes diagnostik dalam bentuk pilihan ganda dengan alasan sebanyak 4 soal yang memenuhi indikator pemahaman konsep notasi, penggeneralisasian, penspesialisasian dan indikator tahapan Mason pada materi operasi himpunan. 
Instrument dalam suatu penelitian perlu divalidasi untuk mengecek kelayakan suatu instrument dipergunakan, dalam penelitin ini terdiri dari 2 validator yaitu yang berasal dari dosen FKIP Matematika UNTAN DAN guru matematika kelas VII SMP LKIA Pontianak. Wawancara dalam penelitian ini dilakukan pada subjek yang diambil secara acak sebanyak empat orang subjek dengan kategori dari yang paling banyak melakukan kesalahan sampai yang paling sedikit yang melakukan kesalahan. Data miskonsepsi subjek dipaparkan sesuai dengan instrument tes diagnostik dalam bentuk pilihan ganda dengan alasan.

Pemilihan subjek yang digunakan dalam penelitian ini didasarkan oleh hasil tes yang telah dijawab oleh siswa diamana tes terebut dilengkapi kriteria CRI yang wajib diisi oleh siswa berdasarkan kenyataan yang ada. Sebanyak 15 siswa kelas VII SMP LKIA Pontianak, peneliti melakukan pengidentifikasian pada jawab masing-masing kepada calon subjek penelitian ini. Dari hasil penelitian tersebut, peneliti memilah siswa yang paham konsep, miskonsepsi, dan tidak paham konsep berdasarkan pedoman analisis untuk tes diagnostic CRI termodifikasi. Subjek yang dipilih adalah jawaban benar alasannya salah dan nilai CRInya (> 2,5), jawaban salah alasannya benar dan nilai CRInya (> 2,5), jawaban salah alsannya salah dan nilai CRInya (> 2,5). Setelah ditentukan siswa yang mengalami miskonsepsi, peneliti melakukan analisis bentuk miskonsepi yang terjadi yaitu terdiri atas miskonsepsi notasi, miskonsepsi penggeneralisasi, dan miskonsepsi penspesialisasian berdasarkan tahapan Mason yang terdiri atas tahapan entry, attack, dan review dan setelah mengetahui bentuk miskonsepsi yang terjadi peneliti melakukan wawancara untuk mengetahui penyebab miskonsepsi yang terjadi pada siswa tersebut. Tahap-tahap analisis yang digunakan dalam penelitian ini adalah data reduction, data display, dan conclusion drawing.

\section{Hasil Penelitian dan Pembahasan}

\subsection{Hasil Penelitian}

Tujuan penelitian ini adalah mengungkap bentuk-bentuk miskonsepsi berdasarkan tahapan Mason dan penyebab miskonsepsi menggunakan yang berasal dari subjek pada materi operasi himpunan. Subjek dalam penelitian ini berjumlah 15 subjek kelas VII SMP LKIA. Miskonsepsi notasi, penggeneralisasi, dan penspesialisasian adalah bentuk miskonsepsi yang terjadi pada siswa dalam menyelesaikan soal operasi himpunan. Penyebab miskonsepsi siswa adalah berasal dari pemikiran asosiatif, reasoning yang tidak lengkap atau salah, dan intuisi yang salah. Berikut ini untuk Tabel 1 dan Tabel 2 merupakan hasil rekapitulasi data yang didapat oleh peneliti setelah melakukan penelitian yang sebenarnya.

Tabel 1 Rekap Data Bentuk Miskonsepsi Siswa

\begin{tabular}{|c|c|c|c|c|c|}
\hline \multirow{2}{*}{$\begin{array}{l}\text { Jumlah } \\
\text { Subjek }\end{array}$} & \multirow{2}{*}{ No soal } & \multirow{2}{*}{ Tahapan Mason } & \multicolumn{3}{|c|}{ Miskonsepsi } \\
\hline & & & MN & MG & MS \\
\hline \multirow{5}{*}{15} & \multirow{5}{*}{1} & \multirow[b]{2}{*}{ Entry } & 3 & & \\
\hline & & & $20 \%$ & & \\
\hline & & \multirow[b]{2}{*}{ Attack } & 8 & & \\
\hline & & & $53,33 \%$ & & \\
\hline & & Review & - & - & - \\
\hline
\end{tabular}


Vol 1 No 22020 Desember 2020

Jurnal AlphaEuclidEdu

\begin{tabular}{|c|c|c|c|c|}
\hline & & - & - & - \\
\hline \multirow{6}{*}{2} & \multirow{2}{*}{ Entry } & 8 & & \\
\hline & & $53,33 \%$ & & \\
\hline & \multirow{2}{*}{ Attack } & 8 & & \\
\hline & & $53,33 \%$ & & \\
\hline & \multirow{2}{*}{ Review } & - & - & - \\
\hline & & - & - & - \\
\hline \multirow{5}{*}{3} & Entry & & & \\
\hline & \multirow[b]{2}{*}{ Attack } & & 2 & \\
\hline & & & $\frac{5}{20 \%}$ & \\
\hline & \multirow{2}{*}{ Review } & - & - & - \\
\hline & & - & - & - \\
\hline \multirow{5}{*}{4} & Entry & & & \\
\hline & \multirow{2}{*}{ Attack } & & 1 & 1 \\
\hline & & & $6,67 \%$ & $6,67 \%$ \\
\hline & \multirow{2}{*}{ Review } & - & - & - \\
\hline & & - & - & - \\
\hline
\end{tabular}

Keterangan:

MN: Miskonsepsi Notasi

MG: Miskonsepsi Penggeneralisasian

MS: Miskonsepsi penspesialisasian

Tabel 2 Rekap Data Penyebab Miskonsepsi

\begin{tabular}{|l|l|l|l|l|}
\hline No & Bentuk & Penyebab & \multicolumn{2}{|l|}{} \\
\cline { 3 - 5 } Soal & Miskonsepsi & PAS & RTL & IYS \\
\hline 1 & MN & 1 & 1 & 4 \\
\hline 2 & MN & & 3 & \\
\hline 3 & MG & & & 2 \\
\hline 4 & MS & & & 1 \\
\hline
\end{tabular}

Keterangan:

PAS :Pemikiran Asosiatif Siswa

RTL:Reasoning yang Tidak Lengkap/Salah

IYS :Intuisi Yang Salah

\subsection{Pembahasan}

Penelitian tentang Analisis miskonsepsi siswa berdasarkan tahapan Mason di kelas VII Sekolah Menengah Pertama dalam menyelesaikan soal operasi himpunan dilaksanakan pada hari kamis, 9 Juli 2020 kepada 15 siswa dan wawancara dilakukan pada hari rabu, 15 Juli 2020. Penelitian ini dilakukan secara daring karena pada saat penelitian negara Indonesia terpapar virus Covid-19, jadi belajar dan pembelajaran di sekolah dilakukan secara daring. Soal tes yang diberikan yaitu tes diagnostik dalam bentuk pilihan ganda dengan alasan sebanyak 4 soal yang memenuhi indikator pemahaman konsep notasi, penggeneralisasian, penspesialisasian dan indikator tahapan Mason pada materi operasi himpunan. Dalam membagikan instrument soal kepada 25 siswa yang ada di kelas 7 SMP LKIA, peneliti menggunakan aplikasi whatsapp untuk membagikan link soal yang dibuat menggunakan google form, dan yang merespon dari 
25 siswa tersebut hanya 15 siswa saja disebabkan oleh berbagai faktor yaitu keterbatasn alat komunikasi moderen contohnya hp, tidak memiliki kuota pada saat waktu tersebut, sinyal yang kurang mendukung dan ada beberapa siswa yang sengaja tidak mengerjakannya. Saat wawancara peneliti melakukan wawancara daring menggunakan chat aplikasi whatsapp kepada empat subjek berdasrkan kriteria yang telah ditetapkan sebelumnya.

Pada soal nomor 1 dengan pertanyaan tentang mengungkapkan notasi dalam himpunan secara verbal ke simbolik terdapat 2 tahapan dalam Mason yang dilalui siswa yang mengami miskonsepsi yaitu tahapan entry dan tahapan attack. Pada tahapan entry ada tiga subjek atau $20 \%$ subjek yang mengalami miskonsepsi, bentuk miskonsepsi yang dialami subjek adalah miskonsepsi notasi. Bentuk miskonsepsi notasi yang terjadi dalam tahapan entry adalah salah pemahaman dalam menentukan notasi dalam himpunan secara verbal ke simbolik pada penulisan tabulasi anggota himpunan dari himpunan yang diketahui didalam soal. Pada tahapan attack ada delapan subjek atau 53,33\% subjek yang mengalami miskonsepsi, bentuk miskonsepsi yang dialami subjek adalah miskonsepsi notasi. Bentuk miskonsepsi notasi yang terjadi dalam tahapan attack adalah salah pemahaman dalam penulisan notasi gabungan dan irisan. LERARN (2008) menyatakan bahwa miskonsepsi notasi yaitu penafsiran yang keliru pada sebuah notasi. Berdasarkan hasil wawancara diketahui penyebab miskonsepsi yang dialami subjek pada soal nomor 1 yaitu pemikiran asosiatif siswa, reasoning yang tidak lengkap/salah, dan intuisi yang salah.

Pada soal nomor 2 dengan pertanyaan tentang Siswa menyatakan notasi dalam himpunan secara simbolik ke verbal terdapat 2 tahapan dalam Mason yang dilalui siswa yang mengalami miskonsepsi yaitu tahapan entry dan tahapan attack. Pada tahapan entry ada delapan subjek atau 53,33\% subjek yang mengalami miskonsepsi, bentuk miskonsepsi yang dialami subjek adalah miskonsepsi notasi. Bentuk miskonsepsi notasi yang terjadi dalam tahapan entry adalah salah pemahaman notasi dalam himpunan secara simbolik ke verbal pada penulisan tabulasi anggota himpunan. Pada tahapan attack ada delapan subjek atau 53,33\% subjek yang mengalami miskonsepsi, bentuk miskonsepsi yang dialami subjek adalah miskonsepsi notasi. Bentuk miskonsepsi notasi yang terjadi dalam tahapan attack adalah salah pemahaman notasi dalam himpunan secara simbolik ke verbal pada dan himpuan yang diketahui didalam soal dan operasi selisih himpunan. Berdasarkan hasil wawancara diketahui penyebab miskonsepsi yang dialami subjek untuk soal nomor 2 yaitu reasoning yang tidak lengkap/salah.

Pada soal nomor 3 dengan pertanyaan tentang siswa menentukan hasil operasi gabungan dan irisan pada himpunan terdapat 1 tahapan dalam tahapan Mason yang dilalui siswa yang mengalami miskonsepsi yaitu tahapan attack. Pada tahapan attack ada tiga subjek atau $20 \%$ subjek yang mengalami miskonsepsi, bentuk miskonsepsi yang dialami subjek adalah miskonsepsi penggeneralisasian. Bentuk miskonsepsi penggeneralisasi yang terjadi dalam tahapan attack adalah kesalahan pada konsep yang dibutuhkan saat melakukan operasi himpunan irisan, gabungan. Menurut Ashlock menyatkan bahwa miskonsepsi penggeneralisasi adalah suatu kesalahan yang dialami 
oleh siswa yang bermula dari pernyataan yang bersifat umum secara berlebihan terhadap sebuah alasan dan siswa tersebut langsung menarik kesimpulan setelah mempunyai informasi yang lebih untuk menyimpulkan. Berdasarkan hasil wawancara diketahui penyebab miskonsepsi yang dialami subjek untuk soal nomor 3 yaitu intuisi yang salah.

Pada soal nomor 4 dengan pertanyaan tentang siswa menentukan hasil operasi gabungan, komplemen, dan selisih pada himpunan terdapat 1 tahapan dalam tahapan Mason yang dilalui siswa yang mengalami miskonsepsi yaitu tahapan attack. Pada tahapan attack ada satu subjek atau $6,67 \%$ yang mengalami bentuk miskonsepsi penggeneralisasian dan pada tahapan attack ada satu subjek atau 6,67\% yang mengalami bentuk miskonsepsi penspesialisasian. Bentuk miskonsepsi penggeneralisasi yang terjadi dalam tahapan attack adalah kesalahan pada konsep yang dibutuhkan saat melakukan operasi himpunan gabungan dan bentuk miskonsepsi penspesialisasian yang terjadi dalam tahapan attack adalah menganggap sebuah konsep dapat digunakan untuk konsep lainnya dalam melakukan operasi gabungan himpunan. Menurut Ashlock (2008: 11) menyatkan bahwa miskonsepsi penspesialisasian adalah bentuk miskonsepsi yang diberasal dari suatu pemikiran yang mengkhususkan sesutu secara berlebihan selama proses pembelajaran. Berdasarkan hasil wawancara diketahui penyebab miskonsepsi yang dialami subjek untuk soal nomor 4 yaitu intuisi yang salah.

Berdasarkan tahapan yang dicetuskan oleh Mason, siswa mengalami miskonsepsi pada tahapan entry dan attack. Tahapan entry adalah tahapan dimulai ketika pertama kali menghadapi pertanyaan dan berakhir ketika telah memulai untuk mencoba memecahkannya, dan pada akhirnya mereka akan menemukan apa yang diketahui dan ditanyakan, pada tahapan ini miskonsepsi yang terjadi pada subjek adalah miskonsepsi notasi, dimana subjek mengalami salah pemahaman dalam menyatakan notasi dalam himpunan secara verbal ke simbolik terbukti berdasarkan Tabel 1 bahwa untuk soal nomor 1 sebanyak tiga subjek atau 20\% subjek yang mengalami miskonsepsi notasi pada tahapan entry dan subjek mengalami salah pemahaman dalam menyatakan notasi dalam himpunan secara simbolik ke verbal terbukti berdasarkan Tabel 1 bahwa untuk soal nomor 2 sebanyak delapan subjek atau 53,33\% subjek yang mengalami miskonsepsi notasi pada tahapan entry.

Pada tahapan attack adalah tahapan bagian yang paling penting dari aktivitas matematika yang dilakukan untuk menyelesaikan masalah, pada tahapan ini miskonsepsi yang terjadi pada subjek adalah miskonsepsi notasi, miskonsepsi penggeneralisasian, dan miskonsepsi penspesialisasian. Miskonsepsi notasi terjadi akibat subjek mengalami salah pemahaman dalam menyatakan notasi dalam himpunan secara verbal ke simbolik terbukti berdasarkan Tabel 1 bahwa untuk soal nomor 1 sebanyak delapan subjek atau 53,33\% subjek mengalami miskonsepsi notasi pada tahapan attack dan subjek mengalami salah pemahaman dalam mengungkapkan notasi dalam himpunan secara simbolik ke verbal terbukti berdasarkan Tabel 1 bahwa untuk soal nomor 2 sebanyak delapan subjek atau 53,33\% subjek mengalami miskonsepsi notasi pada tahapan attack. Miskonsepsi penggeneralisasin terjadi akibat subjek 
mengalami salah pada konsep yang dibutuhkan saat melakukan operasi himpunan terbukti berdasarkan Tabel 1 bahwa untuk soal nomor 3 sebanyak tiga subjek atau 20\% subjek mengalami miskonsepsi penggeneralisasian pada tahapan attack. Miskonsepsi penspesialisasian terjadi akibat subjek yang menganggap sebuah konsep dapat digunakan untuk konsep lainnya terbukti berdasarkan Tabel 1 bahwa untuk soal nomor 4 sebanyak satu subjek atau $6,67 \%$ yang mengalami miskonsepsi penspesialisasian.

Tahapan review tahapan dimana siswa melakukan meninjau kembali dan memeriksa yang mungkin saja terjadi kesalahan-kesalahan pada saat pengerjaan, pada tahapan ini peneliti tidak dapat menganalisis miskonsepsi yang terjadi, karena subjek tidak menuliskan tahapan pengecekan kembali jawaban yang telah dibuatnya terbukti dari foto pengerjaan subjek yang telah dianalisis dan pada Tabel 1. Dari pembahasan di atas dapat dilihat bahwa berdasarkan tahapan Mason yang terdiri atas tahapan entry, attack, dan review, siswa banyak mengalami miskonsepsi pada tahapan entry dan tahapan attack. Dari dua tahapan tersebut yang sering terjadinya miskonsepsi yaitu pada tahapan attack. Hal ini sejalan dalam penelitian Karolin (2016) pada hasil penelitiannya menunjukan bahwa dari tiga tahapan yang dicetuskan oleh Mason, pada tahapan attack siswa mengalami miskonsepsi.

Suparno menyatakan bahwa penyebab miskonsepsi yang berasal dari siswa terdiri atas prakonsepsi, pemikiran asosiatif, pemikiran humanistik, reasoning yang tidak lengkap/salah, intuisi yang salah, tahap perkembangan kognitif siswa, kemampuan siswa, minat belajar (Suparno, 2013). Berdasarkan delapan faktor yang menyebabkan miskonsepsi bersal dari siswa, lima dari tiga faktor tersebut tidak diteliti oleh peneliti dalam penelitian ini yaitu prakonsepsi karena sebelum melaksanakan penelitian yang sebenarnya peneliti harus melakukan wawancara dan tes diagnostik kepada para siswa, pemikiran humanistik tidak diambil karena pemikiran humanistik memandang semua benda dari pandangan manusiawi, sisi-sisi manusiawi yang dimaksudkan adalah adanya keterlibatan otak dan emosi setiap individu dalam kegiatan pembelajaran, jadi peneliti harus melakukan penelitian awal untuk mengetahui pemikiran humanistik setiap siswa setiap kegitan pelajarannya, tahap perkembangan kognitif siswa karena dalam penelitian ini dilakukan kepada siswa kelas VII SMP, sehingga menurut Piaget umur siswa tersebut berada pada masa operasional dengan rentang umur dari sebelas tahun hingga dewasa (dalam Ormrod, 2009 dengan hal ini menyebabkan peneliti beranggapan bahwa siswa mempunyai perkembangan kognitif yang sama, dan untuk minat belajar serta kemampuan siswa peneliti harus menyebarkan angket atau instrument yang tepat untuk mengetahuinya tidak hanya bisa dilakukan dengan wawancara.

Dalam penelitian ini ditemukan penyebab terjadinya miskonsepsi pada subjek disebakan oleh beberapa faktor, yang berasal dalam diri subjek sendiri yaitu pemikiran asosiatif siswa, Reasoning yang tidak lengkap/salah, dan intuisi yang salah. Penyebab miskonsepsi yang paling banyak terjadi adalah Intuisi Salah terlihat dalam Tabel 2.

\section{Kesimpulan}

Kesimpulan yang dapat diperoleh setelah melakukan penelitian yaitu: (1) a) 
Bentuk miskonsepsi yang dialami siswa kelas VII SMP LKIA Pontianak pada materi operasi himpunan adalah bentuk miskonsepsi notasi, miskonsepsi penggeneralisasi, dan miskonsepsi penspesialisasi. Dari tiga bentuk miskonsepsi yang dialami siswa, bentuk miskonsepsi yang paling sering terjadi adalah miskonsepsi notasi. b) Berdasarkan tahapan yang dibuat Mason yang terdiri atas tahapan entry, attack dan review, siswa kelas VII SMP LKIA Pontianak mengalami miskonsepsi pada dua tahapan tersebut yaitu pada tahapan entry dan tahapan attack. Pada tahapan entry siswa mengalami miskonsepsi notasi dan pada tahapan attack siswa mengalami miskonsepsii notasi, miskonsepsi penggeneralisasi dan miskonsepsi penspesialisasian. Dari dua tahapan tersebut yang sering terjadinya miskonsepsi yaitu pada tahapan attack. (2) Penyebab miskonsepsi yang dialami siswa kelas VII SMP LKIA Pontianak disebabkan oleh pemikiran asosiatif siswa, reasoning yang tidak lengkap/salah, dan intuisi yang salah. Dari tiga penyebab miskonsepsi yang dialami siswa, penyebab yang paling banyak terjadi adalah intuisi yang salah.

\section{Referensi}

Ariefia, Evanty, Hellda. 2016. Proses Berpikir Siswa dalam Menyelesaikan Permasalahan pada Materi Trigonometri. Jurnal Pembelajaran Matematika. 1(28). Ashlock. (2008). Misconception and Error Patterns. [online]. http://ptgmedia.pearsoncmg.com/images/9780135009109/downloads/Ashlock_Ch 1_MisconceptionsandErrorPatterns. pdf, diakses tanggal 23 November 2019.

Edogawatte, G. 2011. Secondary School Students' Misconceptions in Algebra. Department of Curriculum, Teaching, and Learning University of Toronto.

LEARN. (2008). Algebra: Some Common Misconceptions. [Online]. http://www.learnquebec.ca/export/sites/learn/en/content/curriculum/mst/document s/algemisc. pdf, diakses tanggal 23 November 2019.

Lin, F. L. 2007. Designing Mathematics Conjecturing Activities to Foster Thinking and Constructing Actively.

[Online]. (http://cried.tsubasa.ac.jp/math/apec/apec2007/paper. pdf, diakses tanggal 4 Febuari 2020).

Mason, J., Burton, L., \& Stacey K. 2010. Thinking Mathematically. Second Edition. Wokingham. UK: Addison Wesley.

Ormord, J.E. (2009). Psikologi Pendidikan Jilid 1. Jakarta: Erlangga.

Ozkan, E.M. 2011. Misconceptions in Radicals in High School Mathematics. ProcediaSocial and Behavioral Sciences (15), 120-127.

Polya, G. 1973. How To Solve It Second Edition. New Jersey: Princeton University Press.

Siregar, Eveline, \& Nara, Hartini. 2010. Teori Belajar dan Pembelajaran. Bogor: Ghalia Indonesia.

Suparno, Paul. 2005. Miskonsepsi dan Perubahan Kosep dalam Pendidikan Fisika. Jakarta: Grasindo.

T, Natalia, Karolin. Miskonsepsi pada Penyelesaian Soal Aljaba Siswa Kelas VIII 
Vol 1 No 22020 Desember 2020

Jurnal AlphaEuclidEdu

Berdasarkan Proses Berpikir Mason. Jurnal Pendidkan. 1(10), 1917-1925.

Tayubi, Y. R., (2005). Identifikasi miskonsepsi pada konsep-konsep fisika dengan menggunakan CRI Certainty of Response Indeks). [online]. (http://file.upi.edu/direktori/jurnal/jurnalmimbar_pendidikan/mimbar_no_32005/I dentifikasi_Miskonsepsi_Pada_Konsep_Konsep_Fisika_Menggunakan_Certainty _Of_Response_Index_(CRIs). pdf, diakses tanggal 24 November 2019. 